\title{
The Effect of Abusive Supervision on Organizational Identification: A Moderated Mediation Analysis
}

\author{
Huseyin Arasli ${ }^{1, *(\mathbb{D}}$, Mustafa Cengiz ${ }^{2}$, Hasan Evrim Arici ${ }^{3}{ }^{(\mathcal{D}}$, Nagihan Cakmakoglu Arici $^{3}$ and Furkan Arasli ${ }^{4}$ \\ 1 Norwegian School of Hotel Management, University of Stavanger, 4036 Stavanger, Norway \\ 2 Faculty of Tourism, Eastern Mediterranean University, TRNC, Via Mersin 10, Gazimagusa 99628, Turkey; \\ mustafa.cengiz@emu.edu.tr \\ 3 Faculty of Social Sciences Tourism Management Department, Cyprus West University, \\ Gazimagusa 99450, Turkey; hasan_evrim.arici@euruni.edu (H.E.A.); heraas1983@yahoo.com (N.C.A.) \\ 4 Department of Nutrition, Dietetics \& Hospitality Management, Auburn University, Auburn, AL 36849, USA; \\ araslif@gmail.com \\ * Correspondence: huseyin.arasli@uis.no
}

Citation: Arasli, H.; Cengiz, M.; Arici, H.E.; Arici, N.C.; Arasli, F. The Effect of Abusive Supervision on Organizational Identification: A Moderated Mediation Analysis. Sustainability 2021, 13, 8468. https:// doi.org/10.3390/su13158468

Academic Editor: Hyo Sun Jung

Received: 5 June 2021

Accepted: 26 July 2021

Published: 29 July 2021

Publisher's Note: MDPI stays neutral with regard to jurisdictional claims in published maps and institutional affiliations.

Copyright: (c) 2021 by the authors. Licensee MDPI, Basel, Switzerland. This article is an open access article distributed under the terms and conditions of the Creative Commons Attribution (CC BY) license (https:// creativecommons.org/licenses/by/ $4.0 /)$.

\begin{abstract}
This study investigated the effect of abusive supervision on employee organizational identification by analyzing the mediating effect of psychological contract violation. In addition, it explored the moderating role of favoritism in the direct association of abusive supervision and organizational identification and the indirect effect through psychological contract violation. A total of 488 seasonal, immigrant, and part-time employees from family-run hotel organizations were surveyed during the data collection process. By utilizing Hayes's macro, we found that abusive supervision and psychological contract violation had a significant negative effect on organizational identification. In addition, the results showed that psychological contract violation mediated the effect of abusive supervision on organizational identification and favoritism moderated the effect of abusive supervision on psychological contract violation. The findings highlight the detrimental effects of favoritism and abusive supervision on employee outcomes in the hospitality industry.
\end{abstract}

Keywords: abusive supervision; favoritism; psychological contract violation; identification; family firms

\section{Introduction}

The hospitality industry is characterized by high-demand job roles and functions [1-3]. These functions usually create work-related pressure and stress for employees within the industry. Furthermore, the nature of hospitality demands a high degree of attention from employees. With such pressure, it is unsurprising that supervisors seeking to get the best out of their subordinates display some abusive behaviors on the job.

According to Tepper et al., abusive supervision is the subordinates' subjective perception of the display of sustained hostile aggression by their supervisor, which can include belittlement, exclusion, and open rebuke-any abusive behavior short of actual physical contact [4]. Given the negative role of this behavior in the sustainable development of organizations, an increasing number of scholars have sought to probe its antecedents to lessen its deleterious effects [5]. A recent empirical study also addressed the role of abusive supervision in retaining employees in service organizations [6]. The authors found that abusive supervision has a significant impact on employees' psychological well-being and turnover intention. Kim et al.'s 2020 study [7] also suggested that abusive supervision is considered a serious threat to the health of the affected employees and the sustainable development of organizations. A close link between organizational leadership/supervision and the sustainable development of organizations was also confirmed by several famous theories and approaches. For example, the service profit chain model developed by Heskett et al. [8] suggested a cascade effect that results in organizations' sustainable performance. 
The authors argued that to achieve sustainable performance service organizations need to first possess a supervisor or leader who can motivate and retain competent employees. Motivating employees plays a significant role in providing high-quality service [9]. Parasuraman et al.'s $[10,11]$ SERVQUAL model also supports this relationship between employee performance and the service quality perception of customers. The authors also suggest that service quality is among the most important antecedents of customer satisfaction and, consequently, customer loyalty. Both these approaches verified this process by assessing the organization's profitability and competitive advantage over rivals. From a sustainability perspective, this process starts with healthy supervision and ends with the organization's financial performance and can be used to assess service companies' sustainable development in the market. That is, leadership or supervisorship is a starting point for ensuring the sustainable development of service organizations in the market. In a similar vein, Barney's [12] resource-based view also contributes to this discussion by developing a conceptual model prioritizing organizational resources (i.e., financial resources, human resources, and physical resources) as a way to gain a sustained competitive advantage. The author suggested that organizational resources, such as supervisors and employees, should have some attributes (i.e., rare, valuable, inimitable, irreplaceable) that encourage the sustainable development of the market. In other words, this theory also confirms that supervisors and employees are among the most important internal resources for achieving sustainable performance in service organizations. Thus, our study has the potential to provide insight regarding the impacts of abusive supervision on employees and organizations' sustainable development in the hospitality sector.

Leadership has emerged as an active domain in theory building and research, presenting a more scientific and evidence-based background that helped to develop scholars' and practitioners' long-standing attention to this concept. For over 60 years, leadership scholars have struggled to clarify the features of leadership that improve firm performance, particularly in the tourism and hospitality industry $[13,14]$. Research over the past half-century has sought to establish why and how some leadership styles are more efficient than others, but the response is elusive and scholars are still trying to clarify numerous issues [15].

Many scholars have investigated positive leadership styles and their influences on employee-level and firm-level outcomes [16,17]. Previous studies have examined positive leadership styles, such as transformational leadership [18,19], servant leadership [14,20], authentic leadership [21], charismatic leadership [22], spiritual leadership [23], and ethical leadership [24], in the hospitality sector. Moreover, many researchers have suggested a foundation of leadership to guarantee the sustainable development of organizations in the hospitality industry [25] because of its complex and dynamic nature $[13,26]$. Other scholars have suggested that leadership influences job performance in the hospitality industry $[27,28]$. Specifically, leadership style, either positive or negative, has a direct effect on employees' performance and attitudes.

Epitropaki and Martin's work found a significant effect of transformational and transactional leadership styles on employee organizational identification [29]. Similarly, Vondey's study found that servant leadership has a significant impact on employee organizational identification [30]. More recently, Fallatah et al. revealed the significant relationship between authentic leadership and employee organizational identification in healthcare organizations [31]. Several scholars have also investigated leadership styles and their effects on employees' performance and quality of work life. Leitão et al.'s pioneering study found that employees who feel supported by their supervisors are more likely to feel that they contribute to the firm's productivity [32].

On the other hand, negative leadership styles were also investigated to test their impacts on employees. To illustrate, Decoster et al.'s pioneering work found that abusive supervision has a significant impact on organizational identification [33]. Considering this background, hospitality organizations are expected to suffer negative effects from abusive supervision in terms of their employees' psychological and behavioral outcomes [34]. 
Based on affective event theory, which posits that affective events within organizations are appraised by individuals cognitively while trying to assess their effect on their personal well-being [35], hospitality employees may attribute negative value to abuse from their supervisor. Employees may then easily believe that their psychological contract with their organization has been breached as members of the management team are considered to be ambassadors of their departments. Moreover, the core argument of affective event theory is that job attitudes and behaviors are influenced by emotional reactions. Recent research has investigated employees' emotional reactions by considering burnout syndrome as a moderating variable in the assessment of employees' quality of their work life and their feelings of contribution to the firm's productivity [36].

Psychological contracts are based on perceived promises and arise when one party believes that another party is obliged to perform certain deeds and behaviors [37]. A psychological contract violation, according to Morrison and Robinson, is an employee's perception that their organization has failed to adequately fulfill its psychological contract [38]. As many prior studies have demonstrated, the concept of the psychological contract and its violation is rooted in the tenets of social relationships: fulfillment or otherwise of the contract will elicit a commensurate reaction or behavior from employees. Identity is a reciprocal notion that is constructed by interacting with others [39]. As for organizational identity, it is generally considered fundamental, distinct, and permanent regarding the nature of an organization [40].

Research into the organizational behavior literature highlights the relevance and importance of employee identification [41]. In organizational contexts, employees may identify with organizations, and their relations with their supervisors or leaders can shape their identification because supervisors represent the organization [42]. The role of supervisors in employee identification has been scarcely studied in the hospitality literature. Although much has been discussed regarding the antecedents and consequences of abusive supervision, research into when and how abusive supervision affects employee outcomes, such as a psychological contract violation (PCV) and organizational identification, is lacking. Therefore, we analyzed the potential effect of abusive supervision on employee organizational identification by focusing on the mediating role of a PCV and the moderating role of favoritism (see Figure 1).

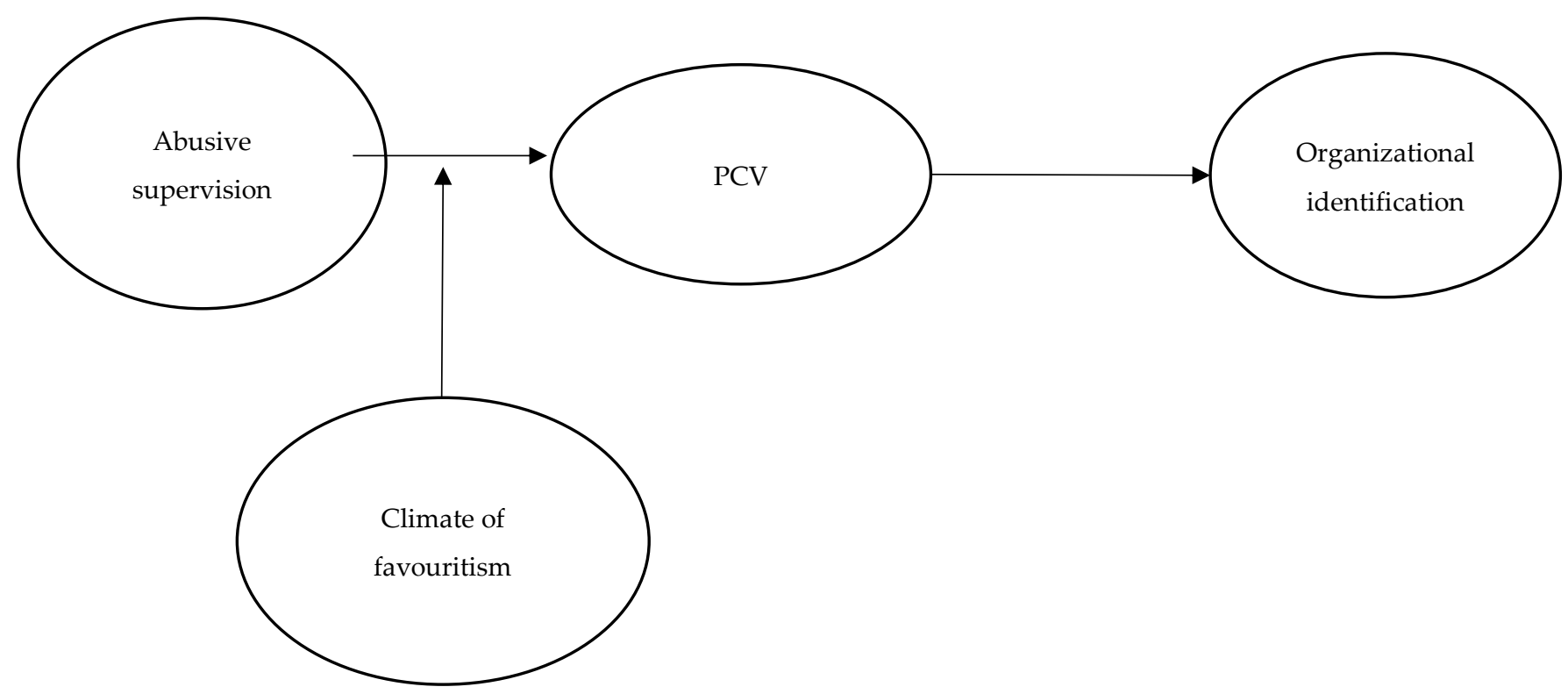

Figure 1. Study model. 


\section{Theoretical Background and Literature Review}

\subsection{Affective Event Theory and Emotional Contagion Theory}

According to Weiss and Cropanzano, affective event theory suggests that people evaluate affective events cognitively, examining the event's associations and importance for their individual wellbeing [35]. That is, organizational events are the proximal causes of affective reactions, where these affective reactions have direct influences on behaviors and attitudes [35]. The outcomes of these appraisals usually lead to behavioral responses and discrete emotions such as anger or joy $[43,44]$. The core tenet of affective event theory is that job attitudes and behaviors are influenced by emotional reactions [35]. Its use in understanding leadership has been well documented in the literature [44-48]. The theory also describes the changes in affective state within a person, how these changes are rooted in regular events, and their effects on simultaneous changes in performance-related conduct [49].

Like affective event theory, emotional contagion theory suggests that discrete emotions within teams or an organization tend to spread across the entire team through a process of contagion [49]. Emotions such as happiness, joy, sadness, and anger may, through the trickle-down effect, transfer from a supervisor to their subordinates. Hatfield et al. argued that emotions are "caught" or picked up in a process of emotional contagion among team members [50].

Affective event theory claims that affective experiences may have attitudinal and behavioral impacts, which were taken into consideration in this study. Numerous studies have asserted the usefulness of understanding how a leader might influence the attitudinal and behavioral experiences of followers in a failure feedback situation. The literature on leadership and emotions is expanding, with much empirical research regarding the impact of leadership on subordinates.

Engle and Lord concluded that a leader's positive affective disposition triggers higherquality leader-member exchanges, as it enhances the trust level or causes the emotion of the leader to "spread" to followers [51]. Studies on mood contagion in nursing, accounting, and sports teams have concluded that the mood of the group leader impacts the overall affective state of all group members [52,53]. If the leader's emotions are positive, the group members' emotions tend to also be positive [54].

On the other hand, some research has focused on the influence of the leader on subordinates' attitudes and work performance. Organizational studies showed that the more positive the leader's affective disposition is, the better the group performance can be when serving customers [55]. George's research also revealed that a more positive group affective tone could make group members more engaged in prosocial organizational behaviors. Consistent with this theory, this study assumes that a supervisor's negative behavior can be detrimental for employees' psychological outcomes, which in turn can negatively affect employees' organizational identification.

\subsection{Abusive Supervision and Psychological Contract Violation}

Workplace conditions affect employees' attitudes and behaviors. This is a core tenet of affective event theory. Abusive supervision may be considered an affective episode with several affective events that span across a certain period [56-58]. Each abusive event, such as verbal aggression, results in an affective reaction. Incidents of abuse may increase the level of negative emotions experienced by the abused subordinates.

Supervisors are often considered representatives of the organization by their subordinates, as most management decisions and directions are communicated to the employees through supervisors. Therefore, if supervisors act in a hostile manner or are abusive toward their subordinates, it can be interpreted as the organization condoning such behaviors. Hence, the perception of a psychological contract breach may be strengthened. In particular, since a breach of a psychological contract is a subjective evaluation, it is easy for abused employees to conclude that the organization has failed to deliver on its promises [59]. 
Since psychological contract fulfillment is important for the emotional stability of the employees and, indirectly, their contribution to organizational performance, a breach of contract must be avoided. Thus, the following hypothesis was proposed:

Hypothesis 1 (H1). Abusive supervision has a positive influence on employees feeling a psychological contract violation has occurred.

\subsection{Psychological Contract Violations and Organizational Identification}

Identity is defined as the essence of an individual or a group. Organizations differ from each other in their ideals, norms, and beliefs, all of which form a unique identity for an organization [60]. These elements of organizational identity also govern the systems, processes, and operations of organizations. Therefore, it is important for the management of service organizations that want to differentiate themselves from the pack to devise mechanisms through which organizational identity is transferred from the visionaries, who are most often top executives, to the lowest-ranked member of staff.

Among other means, psychological contract fulfillment is a way in which the management of a service establishment can motivate their employees into embracing the identity of their organization. In contrast, a psychological contract breach, which is usually defined in the literature as the employees' perception that the promises made by their organization to them have not been fulfilled [61-63], tends to generate negative emotions among employees, making them question the authenticity of the organization's commitment to them, thereby reducing their sense of identification with the organization.

When employees, based on a feeling of injustice or unfairness, feel that their psychological contract has been breached, they are less likely to commit to the norms, ideals, and traditions of the organization. Bearing this in mind, the next hypothesis was proposed:

Hypothesis 2 (H2). Psychological contract violations negatively influence employees' organizational identification.

\subsection{Mediating Role of Psychological Contract Violations}

Abusive supervision, organizational identification, and psychological contract violations are all subjective evaluations or perceptions made by individuals. It is thus expected that their co-existence may impact one another. For example, an employee with a high perception of abuse from their supervisor is highly likely to sense a psychological contract breach and have feelings of alienation from the organization. While abusive supervision may negatively affect employees' feelings of togetherness and belongingness, psychological contract breaches may also act as a mediator between these two constructs such that employees' identification with the organization may be weakened after experiencing a psychological contract breach.

As prior studies have suggested, service organizations must ensure that employees are highly committed and identify with the organization to harness their full potential to achieve customer satisfaction; hence, it is imperative that abuse is prevented in such organizations. Therefore, understanding the mechanism through which abusive supervision impedes employees' identification is critical.

Hypothesis 3 (H3). Psychological contract violations mediate the relationship between abusive supervision and employees' organizational identification.

\subsection{The Moderating Role of a Climate of Favoritism}

Treating workers in a just and equal way causes them to perceive their organization as having kept to its psychological contract [64]. On the other hand, a violation arises if one side perceives that the other side has not kept its promises $[65,66]$. The psychological contract involves an unspoken agreement from the two sides to behave fairly to each other [67]. The disregard or breaking of this agreement can be avoided if the two parties have the same attitude toward liabilities and are aware of how these will be discharged by each side [68]. However, in a work atmosphere that fosters favoritism, it is not possible to 
conduct HR practices in a just and transparent way $[69,70]$ since certain employees might be rewarded owing not to good performance but to being favored by the employer [71]. This kind of treatment could impair the perception of equality in family firms [72,73]. Hence, comprehending the PCV and its possible impacts upon family businesses is necessary for the future of a firm since former research on PCVs has posited that a violation of this agreement could result in higher turnover and lower levels of trust, organizational commitment, and organizational citizenship behaviors [58,59,61,70]. Therefore, we posited the following hypothesis:

Hypothesis 4 (H4). A climate of favoritism moderates the relationship between abusive supervision and employees' psychological contract violation.

The unfavorable work-associated changes that derive from favoritism could produce PCVs in the organization from the perspective of employees. The harmful effects of a work climate of favoritism can also trigger employee perceptions of inequality, especially among non-family-member employees, such as seasonal and migrant workers [74]. Several scholars have suggested that employees' perception of inequality is associated with PCVs and results in negative employee outcomes, such as withdrawal and counterproductive attitudes [75,76]. In addition, recent studies have noted the effects of PCVs in terms of reduced employee satisfaction and organizational commitment $[63,77]$. In such a work environment, the leadership style adopted by supervisors, particularly one that involves favoritism, could decrease the number of employee PCVs by providing fair leadership practices, such as authentic supervision, which can ensure that a family-run organization is still a meritocracy [26]. However, unethical leadership principles, such as abusive supervision, may enhance employees' feeling of a breach of the psychological contract, particularly in family firms, due to favoritism $[26,78]$. Based on the argument that a significantly negative association exists between PCVs and employee organizational identification when favoritism and abusive supervisor practices are adopted, the present study proposes that the indirect effect of abusive supervision on employee identification through PCVs will be stronger in a work climate of favoritism. Therefore, the following hypothesis was posited:

Hypothesis $\mathbf{5}$ (H5). Favoritism will moderate the indirect influence of abusive supervision on employee organizational identity through PCVs such that the indirect influence is stronger when the employee's perception of favoritism is high.

\section{Methodology}

\section{Sample and Procedure}

This research gathered data from 23 family-run hotel organizations in Antalya, Turkey, between July and September 2019. The cover letter included a question that was used to identify the participant's job position in the work setting (i.e., seasonal, migrant, or parttime employee) to differentiate the study sample, followed by a brief paragraph clarifying the aim of the study and a guarantee of anonymity. The cover letter, as well as the survey, was distributed by a researcher to all participating employees. We used the judgmental sampling method to choose seasonal, migrant, and part-time hotel employees from the population, utilizing the above-indicated question. Family hotels were included because these firms had more potential to incorporate favoritism-oriented management practices in the work setting because of the close relationships between family members [26].

Drawing on the guidelines produced by [79], a one-month time lag was used to control for common method variance (CMV). In total, 700 questionnaires were delivered to the employees at time I, of which 612 (87.4\%) were returned. Afterward, 612 time II surveys were distributed, with 495 returned. After sorting through the returned questionnaires and removing invalid questionnaires with incomplete information, 488 questionnaires were considered valid, which provided a response rate of $69.7 \%$. 


\section{Measures}

\subsection{Abusive Supervision}

This study measured abusive supervision using the 15-item scale developed by [80]. A sample item is "My supervisor gives me the silent treatment." A five-point Likert scale was used to anchor this measurement, with 1 meaning strongly disagree and 5 meaning strongly agree.

\subsection{Psychological Contract Violations}

To measure psychological contract violations, we adopted Morrison and Robinson's 4-item scale [63]. A sample item was "I feel that this organization has violated the contract between us." A five-point Likert scale was used, ranging from 1 (strongly disagree) to 5 (strongly agree).

\subsection{Organizational Identification}

Organizational identification was measured with a 6-item scale adapted from Mael and Ashforth [81]. A sample item is "When I talk about this organization, I usually say 'we' rather than 'they'." The anchor response scale ranges from 1 (strongly disagree) to 5 (strongly agree).

\subsection{A Climate of Favoritism}

Favoritism was measured using a 5-item scale adapted from Arasli and Tumer [82]. The scale was tested with a 5-point Likert scale that ranged from 1 (strongly disagree) to 5 (strongly agree).

All survey items were originally developed in English and then translated into Turkish using the back-translation method [83]. Afterward, two academics fluent in both languages controlled the items to ensure that the items' content was cross-linguistically comparable and generated the identical context.

The respondents included 327 men (67.0\%) and 161 women (33.0\%). Regarding age, approximately one-third of the participants were aged between 26 and 34, 18.2\% between 18 and 25 years, and $27.9 \%$ between 36 and 40 years, while the remainder were older than 41. In terms of education, $70.1 \%$ held a senior high school degree or below, $18.9 \%$ held a two-year junior college degree, and $14.7 \%$ had received a bachelor's degree or higher. Of the participants, $52.6 \%$ had an organizational tenure of two years or less. Of the 488 respondents, $14.3 \%$ were part-time workers, $46.1 \%$ were seasonal employees, and 39.5\% were migrant workers.

\section{Data Analysis}

Following Anderson and Gerbing [77], we performed a confirmatory factor analysis (CFA) to examine the convergent and discriminant validities of the study variables. The reliabilities were tested via the threshold value of 0.70 . In addition, to test the links between variables, a correlation analysis was performed. We adopted a moderated mediation model in which PCVs were utilized as the mediator and a culture of favoritism was the moderator. Hence, Hayes's process macro was conducted to examine the moderated mediation effect [84].

\section{Results}

\subsection{Validation of the Measurement Model}

To test the measurement model, the CFA estimated the internal consistency for the latent variables and determined whether construct validity existed. The findings showed that the measurement model fit the data excellently $\left(\chi^{2}=938.76, \mathrm{df}=408, p<0.001\right.$, $\left.\chi^{2} / \mathrm{df}=2.301, \mathrm{RMSEA}=0.067, \mathrm{CFI}=0.94, \mathrm{IFI}=0.91, \mathrm{TLI}=0.90\right)$. The items were significantly loaded onto their related latent construct $(p<0.01)$. The factors involved a high degree of composite reliability, ranging from 0.83 to 0.90 . Thus, reliability was evident since the value of composite reliability exceeded the minimum value of 0.70 [85]. The 
average variance extracted (AVE) scores varied from 0.61 to 0.79 and exceeded 0.05 (see Appendix A). Hence, convergent validity was supported [85]. In addition, the squared scores of correlations between a pair of constructs did not exceed the AVE scores, which verified the discriminant validity [86].

\subsection{Descriptive Statistics}

In the first step, analyses of the descriptive statistics and bivariate correlations were performed. Table 1 shows the mean scores, standard deviations, and correlations between the variables. As seen in Table 1, all hypothesized relationships were as expected $(p<0.01)$.

Table 1. Correlation matrix.

\begin{tabular}{lccccccc}
\hline \multicolumn{1}{c}{ Variables } & Means & SD & $\mathbf{1}$ & $\mathbf{2}$ & $\mathbf{3}$ & $\mathbf{4}$ & \\
\hline 1. Abusive supervision & 2.34 & 0.99 & $(0.81)$ & & & & \\
2. PCV & 2.21 & 1.03 & $0.452^{* *}$ & & $(0.89)$ & & \\
3. Organizational & 3.04 & 0.73 & $0.317^{* *}$ & & $0.351 * *$ & $(0.95)$ & \\
identification & 2.27 & 0.80 & $0.477^{* *}$ & $0.522^{* *}$ & & $-0.510^{* *}$ & $(0.95)$ \\
4. Favoritism & &
\end{tabular}

Note: SD—standard deviation, PCV—psychological contract violation. Values in parentheses provide the internal consistencies (Cronbach's alpha); ${ }^{* *} p<0.01$.

\subsection{Hypothesis Testing}

The findings show that abusive supervision had a significant and positive effect on PCVs $(\beta=0.45, p<0.01)$, providing support for H1. In addition, the findings confirmed that PCVs had a negative and significant effect on employee organizational identity $(\beta=-0.35$, $p<0.01$ ). Thus, $\mathrm{H} 2$ was also supported (see Table 2).

Table 2. Hypothesis testing: regression analysis.

\begin{tabular}{cccc}
\hline PCV & Organizational Identification & $\boldsymbol{\beta}$ & $\mathbf{t}$ \\
\hline Constant & $1.11^{* *}$ & & $3.59(0.07)$ \\
Abusive supervision & 0.45 & $11.17^{* *}$ & $-8.26^{* *}$ \\
PCV & 0.20 & -0.35 & \\
$R^{2}$ & & 0.12 &
\end{tabular}

H3 proposed the mediating effect of PCVs on the relationship between abusive supervision and organizational identity. To test this mediation effect, we adopted the conditions produced by Preacher and Hayes [87]. The guidelines included:

1. Assuming a significant relationship between the independent variable (abusive supervision) and the mediator (PCVs) (Table 3, model 1, $\mathrm{b}=0.47, p<0.01$ );

2. Estimating the significant relationship between the mediator and the dependent variable (organizational identity) (model $2, b=-0.18, p<0.01$ ) when controlling for the influence of the independent variable (model $2, \mathrm{~b}=-0.15, p<0.01$ );

3. Bootstrapping the sampling distribution of indirect influence and determining the confidence interval $(\mathrm{CI})$ with the statistical results from the bootstrapped sampling distribution.

Table 3. Testing the mediating role of OID.

\begin{tabular}{ccc}
\hline Variables & Model 1 & Model 2 \\
\hline & DV: PCV & DV: Organizational Identity \\
Abusive supervision & $0.47(0.04)^{* *}$ & $-0.15(0.03)^{* *}$ \\
PCV & - & $-0.18(0.03)^{* *}$ \\
$R^{2}$ & 0.20 & 0.15 \\
\hline
\end{tabular}

Note: $n=488$; values corresponding to the independent constructs are coefficient impacts, $\beta$, with standard errors given in parentheses. PCV-psychological contract violation. ${ }^{* *} p<0.01$. 
The indirect influence via PCVs was estimated to be between -0.16 and -0.07 with $95 \%$ confidence and normal theory tests $(z=-7.91, p<0.01)$. Since there was no zero within the confidence interval, the indirect influences were significantly above zero and PCVs mediated the relationship between abusive supervision and organizational identity, supporting $\mathrm{H} 3$.

H4 proposed that a climate of favoritism moderates the relationship between abusive supervision and PCVs. The proposed interaction of abusive supervision $\times$ climate of favoritism $(b=0.11, p<0.01)$ was significant and thus supported H4 (see Table 4).

Table 4. Moderator effect of favoritism.

\begin{tabular}{cc}
\hline Variables & DV: PCV \\
\hline Constant & $2.17(0.04)^{* *}$ \\
Abusive supervision & $0.26(0.05)^{* *}$ \\
Climate of favoritism & $0.52(0.06)^{* *}$ \\
Interaction: & $0.11(0.04)^{* *}$ \\
Abusive supervision $\times$ Climate of favoritism & 0.33
\end{tabular}

Note: $n=488$; values show coefficient effects of independent variables, $\beta$, with standard errors given within parentheses. PCV—psychological contract violation. ${ }^{* *} p<0.01$.

H5 suggested a conditional indirect effect such that the indirect influence of abusive supervision on organizational identity would be moderated by a climate of favoritism. The conditional indirect influence of abusive supervision via PCVs is illustrated in Table 5. Notably, the indirect influence of abusive supervision through PCVs under a more pronounced climate of favoritism $(b=-0.03)$ was stronger than that under a less obvious climate of favoritism $(b=-0.06)$. The moderated mediation index provides additional support [84]. The index was significant when PCVs were added into the model as a mediator (effect $=-0.03, \mathrm{SE}=0.01,95 \% \mathrm{CI}=[-0.103,-0.03])$. These empirical findings show that the indirect influence of abusive supervision on organizational identity through the mediating role of PCVs was enhanced as the climate of favoritism increased. Thus, H5 was also supported.

Table 5. Conditional effect of abusive supervision on organizational identity through PCV for distinct scores of favoritism.

\begin{tabular}{cccccc}
\hline Mediator & Decentralization & Effect & SE & LLCI & ULCI \\
\hline PCV & -1 SD & -0.03 & 0.01 & -0.60 & -0.13 \\
\hline 0 & -0.04 & 0.01 & -0.76 & -0.26 \\
\hline & +1 SD & -0.06 & 0.02 & -0.103 & -0.03 \\
\hline
\end{tabular}

\section{Discussion}

This work outlined the predictors and psychological mechanisms of organizational identification (OID) by focusing on the fundamental influence of abusive supervision (AS), the mediating role of PCVs, and the moderating role of a climate of favoritism. The study findings demonstrate that abusive supervision was significantly associated with psychological contract violation, and the association was more powerful for employees encountering a stronger climate of favoritism in family-run organizations. Moreover, PCVs mediated the joint influence of a climate of favoritism and abusive supervision on OID.

\subsection{Theoretical Implications}

Based on both affective event and emotional contagion theories, we examined the influence of AS on OID by examining the mediating role of PCVs. Moreover, we investigated the moderating effect of a climate of favoritism on the association between the extent of PCVs and OID and the indirect relationship between AS and OID. PCVs mediated the 
relationship between abusive supervision and OID. Furthermore, a climate of favoritism moderated the direct effect of PCVs on OID, and the indirect effect of AS on OID through the extent of PCVs.

The study helped us to understand how PCVs impacted the relationship between AS and OID and how a climate of favoritism moderated its direct and indirect effects on OID using a sample of 23 family-run hotels. The findings suggested that AS significantly affected OID, which corroborates the empirical findings of Decoster et al. [33], Liu et al. [88], and Wei and $\mathrm{Si}$ [89]. Our results also show that PCVs were related to OID. This is consistent with prior research [59,90-92] in that the combination of abusive leadership practices and PCVs significantly influences OID. Additionally, PCVs mediated the relationship between AS and OID. Therefore, our results are consistent with previous studies [88], indicating that AS is one of the important antecedents of PCVs, which subsequently determines the OID of the employees in the research content. Another important outcome of this study was the empirically evidenced relationship between a climate of favoritism and PCVs by the employees to produce a negative influence on OID. This work has attracted interest regarding the detrimental influences of a climate of favoritism on affective PCVs. In particular, a greater volume of PCV measures is linked with an enhanced OID, but only when the climate of favoritism of such hotels is more obvious. Simply stated, better managerial outcomes could be accomplished regarding OID if abusive supervision is replaced by ethical leadership.

In short, a climate of favoritism moderated the relationship between PCVs and OID. Therefore, this study contributes to the PCV literature by identifying crucial and new situations under which PCVs influence OID. Finally, our study confirmed the relationships between AS, PCVs, and OID by analyzing the boundary conditions of a climate of favoritism from the perspective of contingent employees. The indirect influence of AS on OID through PCVs was stronger when the climate of favoritism was high; this means that, in organizations where AS did exist, OID was lowered only when the climate of favoritism was strong. To sum up, simultaneously including PCVs and a climate of favoritism in the hypothesized relationships facilitated the comprehension of AS, as well as its link to OID.

Our findings also contribute to the sustainability literature. The contribution of our study is at least twofold. First, by empirically examining the role of AS in OID, we confirmed the importance of the dark side of leadership in hospitality organizations. This implies that AS needs to be considered as an important agent of service organizations that leads to changes in employees' behaviors and attitudes, which in turn leads to organizations' sustainable development in the market. This important finding is congruent with previous empirical studies $[6,7]$ that suggested that AS is an important factor that affects organizations' sustainable development in service industries. Thus, our study extended our understanding regarding AS and we call for further research on its direct impacts on the sustainable performance of organizations. Second, our empirical findings also endorsed several theoretical guidelines that suggest the important role of internal resources, such as managers, supervisors, and employees, in achieving sustained competitive advantage in the market $[8,12]$. This theoretical knowledge was shown by our empirical findings by revealing the role of AS in affecting employee OID via PCVs. Our findings also contribute to previous research [93] that revealed the relationship between leadership and OID in hotel organizations. This brings with itself a new question: does abusive supervision have an indirect effect on organizations' sustainable performance via OID or is there a significant relationship between a higher level of OID and the sustainable development of organizations?. Simply stated, this study opens up a new avenue through which to examine the role of abusive supervision in the sustainability literature, which has received surprisingly little attention from sustainability researchers.

\subsection{Practical Implications}

Several implications may be identified from the findings of this work. First, PCVs trigger aggrieved employees to act abusively toward their peers and customers. Thus, 
hotel management ought to try to steer clear of the negative impacts connected with psychological contracts by avoiding impractical promises made during selection, orientation, promotion, rewarding, and job communications. According to Arasli et al. [94], management promises might be raising expectations and could be motivating in the short term, but in the long term, they might harm both workers and companies if the promises are not kept. If AS is inevitable, feelings of anger and distrust might be reduced and staff trust increased via an ethical, authentic leadership style [63].

Furthermore, hospitality specialists can benefit from this study by familiarizing themselves with the antecedents of OID to find ways to improve their management practices. The results specify that AS negatively affected OID, especially due to the undesired contribution of favoritism in family organizations. Practitioners might thus try to develop human resources policies, such as recruitment and selection policies, making them more transparent and efficient in terms of organizational outcomes.

\subsection{Limitations and Future Research Directions}

Like its predecessors, this study suffered from some limitations. First, although the sample included three different employment types, namely, seasonal, migrant, and parttime employees, all three were considered as one group and we ignored their potential differences. Future studies could focus on the differences between the employment types to expand our understanding of the proposed model. Second, the study's findings relied on data gathered from a single source (i.e., employees). Thus, collecting data from multiple sources, including employees and supervisors, and comparing their answers would pay dividends. Third, in this study, family firms were considered, and other types of hospitality organizations were not included. Future examinations could include other types of hotels. Fourth, future studies could also examine the potentially detrimental effects of AS on other employee outcomes, such as engagement, citizenship behaviors, and job embeddedness. Last but not least, future studies could adopt a longitudinal approach to obtain stronger findings on the hypothesized relationships suggested in the study model.

Author Contributions: Conceptualization, H.A., H.E.A. and N.C.A.; methodology, F.A. and M.C.; software, F.A.; validation, M.C. and F.A.; formal analysis, H.A.; investigation, H.E.A.; resources, N.C.A.; data curation, F.A.; writing—original draft preparation, H.A., M.C.; writing—review and editing, H.E.A., N.C.A.; visualization, F.A.; supervision, H.A.; project administration, H.A., H.E.A.; funding acquisition, M.C. All authors have read and agreed to the published version of the manuscript.

Funding: This research received no external funding.

Institutional Review Board Statement: The study was conducted according to the guidelines of the Declaration of Helsinki, and approved by the Institutional Review Board (or Ethics Committee) of Eastern Mediterranean University.

Informed Consent Statement: Not applicable.

Data Availability Statement: MDPI Research Data Policies.

Acknowledgments: Not applicable.

Conflicts of Interest: The authors declare no conflict of interest. 


\section{Appendix A. Measurement Parameter Estimates}

\begin{tabular}{|c|c|c|c|}
\hline & $\begin{array}{l}\text { Standardized } \\
\text { Loading }\end{array}$ & CCR & AVE \\
\hline Abusive supervision & & 0.85 & 0.67 \\
\hline \multicolumn{4}{|l|}{ My supervisor: } \\
\hline Ridicules me. & 0.81 & & \\
\hline Tells me my thoughts or feelings are stupid. & 0.69 & & \\
\hline Gives me the silent treatment. & 0.77 & & \\
\hline Puts me down in front of others. & 0.85 & & \\
\hline Invades my privacy. & 0.85 & & \\
\hline Reminds me of my past mistakes and failures. & 0.68 & & \\
\hline Doesn't give me credit for jobs requiring a lot of effort. & 0.70 & & \\
\hline Blames me to save himself/herself embarrassment. & 0.72 & & \\
\hline Breaks promises he/she made. & 0.69 & & \\
\hline $\begin{array}{l}\text { Expresses anger at me when he/she is mad for another } \\
\text { reason. }\end{array}$ & 0.81 & & \\
\hline Makes negative comments about me to others. & 0.75 & & \\
\hline Is rude to me. & 0.71 & & \\
\hline Does not allow me to interact with my coworkers. & 0.71 & & \\
\hline Tells me I'm incompetent. & 0.74 & & \\
\hline Lies to me. & 0.76 & & \\
\hline Favoritism & & 0.88 & 0.63 \\
\hline $\begin{array}{l}\text { Employees of this hotel always feel that they need } \\
\text { friends and acquaintances in a high-level position. }\end{array}$ & 0.80 & & \\
\hline Employees who are promoted or rewarded only & & & \\
\hline $\begin{array}{l}\text { because of close friendship ties are a negative influence } \\
\text { on this organization. }\end{array}$ & 0.77 & & \\
\hline Executives' close friends are frustrated by never really & & & \\
\hline $\begin{array}{l}\text { knowing whether they were appointed because of their } \\
\text { talent or friendship ties. }\end{array}$ & 0.86 & & \\
\hline Friends and acquaintances' disagreements become & & & \\
\hline $\begin{array}{l}\text { business problems in organizations allowing } \\
\text { favoritism. }\end{array}$ & 0.81 & & \\
\hline $\begin{array}{l}\text { Executives are more interested in keeping friends and } \\
\text { acquaintances in good positions than they are in those } \\
\text { employees' performance or the organization's } \\
\text { profitability. }\end{array}$ & 0.79 & & \\
\hline Organizational identity & & 0.83 & 0.61 \\
\hline $\begin{array}{l}\text { When someone criticizes this organization, it feels like } \\
\text { a personal insult. }\end{array}$ & 0.77 & & \\
\hline $\begin{array}{l}\text { I am very interested in what others think about this } \\
\text { organization. }\end{array}$ & 0.76 & & \\
\hline $\begin{array}{l}\text { When I talk about this organization, I usually say "we" } \\
\text { rather than "they." }\end{array}$ & 0.82 & & \\
\hline This organization's successes are my successes. & 0.70 & & \\
\hline $\begin{array}{l}\text { When someone praises this organization, it feels like a } \\
\text { personal compliment. }\end{array}$ & 0.72 & & \\
\hline $\begin{array}{l}\text { I act like a (name of organization) person to a great } \\
\text { extent. }\end{array}$ & 0.72 & & \\
\hline Psychological contract violation & & 0.90 & 0.79 \\
\hline $\begin{array}{l}\text { I feel that my organization has violated the contract } \\
\text { between us. }\end{array}$ & 0.85 & & \\
\hline $\begin{array}{l}\text { I feel extremely frustrated by how I have been treated } \\
\text { by my organization. }\end{array}$ & 0.91 & & \\
\hline I feel betrayed by my organization. & 0.86 & & \\
\hline $\begin{array}{l}\text { My employer has broken many of their promises to me } \\
\text { even though I've upheld my side of the deal. }\end{array}$ & 0.73 & & \\
\hline
\end{tabular}




\section{References}

1. Chiang, F.F.; Birtch, T.A.; Kwan, H.K. The moderating roles of job control and work-life balance practices on employee stress in the hotel and catering industry. Int. J. Hosp. Manag. 2010, 29, 25-32. [CrossRef]

2. Chiang, F.F.; Birtch, T.A.; Cai, Z. Front-line service employees' job satisfaction in the hospitality industry: The influence of job demand variability and the moderating roles of job content and job context factors. Cornell Hosp. Q. 2014, 55, 398-407. [CrossRef]

3. Singal, M. How is the hospitality and tourism industry different? An empirical test of some structural characteristics. Int. J. Hosp. Manag. 2015, 47, 116-119. [CrossRef]

4. Tepper, B.J.; Moss, S.E.; Duffy, M.K. Predictors of abusive supervision: Supervisor perceptions of deep-level dissimilarity, relationship conflict, and subordinate performance. Acad. Manag. J. 2011, 54, 279-294. [CrossRef]

5. Li, Z.; He, B.; Sun, X.; Zhang, Y. Demonstrating the psychological aspects of stressors and abusive supervision behavior: Attainment of sustainability under the rubric of resources theory. Front. Psychol. 2020, 11, 293. [CrossRef]

6. Hussain, K.; Abbas, Z.; Gulzar, S.; Jibril, A.B.; Hussain, A. Examining the impact of abusive supervision on employees' psychological wellbeing and turnover intention: The mediating role of intrinsic motivation. Cogent Bus. Manag. 2020, 7, 1818998. [CrossRef]

7. Kim, H.; Chen, Y.; Kong, H. Abusive supervision and organizational citizenship behavior: The mediating role of networking behavior. Sustainability 2020, 12, 288. [CrossRef]

8. Heskett, J.L.; Jones, T.O.; Loveman, G.W.; Sasser, W.E.; Schlesinger, L.A. Putting the service-profit chain to work. Harv. Bus. Rev. 1994, 72, 164-174.

9. Arasl1, H.; Arıc1, H.E. The art of retaining seasonal employees: Three industry-specific leadership styles. Serv. Ind. J. 2019, 39, 175-205. [CrossRef]

10. Parasuraman, A.; Zeithaml, V.A.; Berry, L.L. A conceptual model of service quality and its implications for future research. J. Mark. 1985, 49, 41-50. [CrossRef]

11. Parasuraman, A.; Zeithaml, V.A.; Berry, L. SERVQUAL: A multiple-item scale for measuring consumer perceptions of service quality. 1988 1988, 64, 12-40.

12. Barney, J. Firm resources and sustained competitive advantage. J. Manag. 1991, 17, 99-120. [CrossRef]

13. Arasli, H.; Altinay, L.; Arici, H.E. Seasonal employee leadership in the hospitality industry: A scale development. Int. J. Contemp. Hosp. Manag. 2020, 32, 2195-2215. [CrossRef]

14. Chon, K.K.-S.; Zoltan, J. Role of servant leadership in contemporary hospitality. Int. J. Contemp. Hosp. Manag. 2019. [CrossRef]

15. Gordon, A.; Yukl, G. The future of leadership research: Challenges and opportunities. Ger. J. Hum. Resour. Manag. 2004, 18, 359-365. [CrossRef]

16. Anser, M.K.; Ali, M.; Usman, M.; Rana, M.L.T.; Yousaf, Z. Ethical leadership and knowledge hiding: An intervening and interactional analysis. Serv. Ind. J. 2021, 41, 307-329. [CrossRef]

17. Cavazotte, F.; Moreno, V.; Lasmar, L.C.C. Enabling customer satisfaction in call center teams: The role of transformational leadership in the service-profit chain. Serv. Ind. J. 2020, 40, 380-393. [CrossRef]

18. Kara, D.; Uysal, M.; Sirgy, M.J.; Lee, G. The effects of leadership style on employee well-being in hospitality. Int. J. Hosp. Manag. 2013, 34, 9-18. [CrossRef]

19. Tracey, J.B.; Hinkin, T.R. Transformational leaders in the hospitality industry. Cornell Hotel Restaur. Adm. Q. 1994, 35, 18-24. [CrossRef]

20. Koyuncu, M.; Burke, R.J.; Astakhova, M.; Eren, D.; Cetin, H. Servant leadership and perceptions of service quality provided by front-line service workers in hotels in Turkey: Achieving competitive advantage. Int. J. Contemp. Hosp. Manag. 2014. [CrossRef]

21. Arici, H.E. Perceived supervisor support and turnover intention: Moderating effect of authentic leadership. Leadersh. Organ. Dev. J. 2018. [CrossRef]

22. Tuan, L.T. Catalyzing employee OCBE in tour companies: Charismatic leadership, organizational justice, and pro-environmental behaviors. J. Hosp. Tour. Res. 2019, 43, 682-711. [CrossRef]

23. Bayighomog, S.W.; Arasl, H. Workplace spirituality-customer engagement Nexus: The mediated role of spiritual leadership on customer-oriented boundary-spanning behaviors. Serv. Ind. J. 2019, 39, 637-661. [CrossRef]

24. Schwepker Jr, C.H.; Dimitriou, C.K. Using ethical leadership to reduce job stress and improve performance quality in the hospitality industry. Int. J. Hosp. Manag. 2021, 94, 102860. [CrossRef]

25. Huang, J.; Li, W.; Qiu, C.; Yim, F.H.-k.; Wan, J. The impact of CEO servant leadership on firm performance in the hospitality industry. Int. J. Contemp. Hosp. Manag. 2016. [CrossRef]

26. Arasli, H.; Arici, H.E.; Çakmakoğlu Arici, N. Workplace favouritism, psychological contract violation and turnover intention: Moderating roles of authentic leadership and job insecurity climate. Ger. J. Hum. Resour. Manag. 2019, 33, 197-222. [CrossRef]

27. Elbaz, A.M.; Haddoud, M.Y. The role of wisdom leadership in increasing job performance: Evidence from the Egyptian tourism sector. Tour. Manag. 2017, 63, 66-76. [CrossRef]

28. Walumbwa, F.O.; Hartnell, C.A.; Misati, E. Does ethical leadership enhance group learning behavior? Examining the mediating influence of group ethical conduct, justice climate, and peer justice. J. Bus. Res. 2017, 72, 14-23. [CrossRef]

29. Epitropaki, O.; Martin, R. The moderating role of individual differences in the relation between transformational/transactional leadership perceptions and organizational identification. Leadersh. Q. 2005, 16, 569-589. [CrossRef]

30. Vondey, M. The relationships among servant leadership, organizational citizenship behavior, person-organization fit, and organizational identification. Int. J. Leadersh. Stud. 2010, 6, 3-27. 
31. Fallatah, F.; Laschinger, H.K.; Read, E.A. The effects of authentic leadership, organizational identification, and occupational coping self-efficacy on new graduate nurses' job turnover intentions in Canada. Nurs. Outlook 2017, 65, 172-183. [CrossRef]

32. Leitão, J.; Pereira, D.; Gonçalves, Â. Quality of work life and organizational performance: Workers' feelings of contributing, or not, to the organization's productivity. Int. J. Environ. Res. Public Health 2019, 16, 3803. [CrossRef]

33. Decoster, S.; Camps, J.; Stouten, J.; Vandevyvere, L.; Tripp, T.M. Standing by your organization: The impact of organizational identification and abusive supervision on followers' perceived cohesion and tendency to gossip. J. Bus. Ethics 2013, 118, 623-634. [CrossRef]

34. Ma, J.; Zhou, X.; Mu, Z. Can abusive supervision motivate customer-oriented service sabotage? A multilevel research. Serv. Ind. J. 2021, 41, 696-717. [CrossRef]

35. Weiss, H.M.; Cropanzano, R. Affective events theory: A theoretical discussion of the structure, causes and consequences of affective experiences at work. In Research in Organizational Behavior: An Annual Series of Analytical Essays and Critical Reviezw; Elsevier Science: Amsterdam, The Netherlands, 1996; Volume 18, pp. 1-74.

36. Leitão, J.; Pereira, D.; Gonçalves, Â. Quality of work life and contribution to productivity: Assessing the moderator effects of burnout syndrome. Int. J. Environ. Res. Public Health 2021, 18, 2425. [CrossRef] [PubMed]

37. Rousseau, D. Psychological Contracts in Organizations: Understanding Written and Unwritten Agreements; Sage Publications: Thousand Oaks, CA, USA, 1995.

38. Morrison, E.W.; Robinson, S.L. When employees feel betrayed: A model of how psychological contract violation develops. Acad. Manag. Rev. 1997, 22, 226-256. [CrossRef]

39. Dutton, J.E.; Dukerich, J.M. Keeping an eye on the mirror: Image and identity in organizational adaptation. Acad. Manag. J. 1991, 34, 517-554.

40. Gioia, D.A.; Schultz, M.; Corley, K.G. Organizational identity, image, and adaptive instability. Acad. Manag. Rev. 2000, 25 , 63-81. [CrossRef]

41. Fiol, C.M.; O'Connor, E.J. When hot and cold collide in radical change processes: Lessons from community development. Organ. Sci. 2002, 13, 532-546. [CrossRef]

42. Eisenberger, R.; Stinglhamber, F.; Vandenberghe, C.; Sucharski, I.L.; Rhoades, L. Perceived supervisor support: Contributions to perceived organizational support and employee retention. J. Appl. Psychol. 2002, 87, 565. [CrossRef]

43. Lin, C.P.; He, H.; Baruch, Y.; Ashforth, B.E. The effect of team affective tone on team performance: The roles of team identification and team cooperation. Hum. Resour. Manag. 2017, 56, 931-952. [CrossRef]

44. Pirola-Merlo, A.; Härtel, C.; Mann, L.; Hirst, G. How leaders influence the impact of affective events on team climate and performance in R\&D teams. Leadersh. Q. 2002, 13, 561-581.

45. Lin, B.; Law, K.S.; Zhou, J. Why is underemployment related to creativity and OCB? A task-crafting explanation of the curvilinear moderated relations. Acad. Manag. J. 2017, 60, 156-177. [CrossRef]

46. Qu, R.; Janssen, O.; Shi, K. Leader-member exchange and follower creativity: The moderating roles of leader and follower expectations for creativity. Int. J. Hum. Resour. Manag. 2017, 28, 603-626. [CrossRef]

47. Meng, Y.; Tan, J.; Li, J. Abusive supervision by academic supervisors and postgraduate research students' creativity: The mediating role of leader-member exchange and intrinsic motivation. Int. J. Leadersh. Educ. 2017, 20, 605-617. [CrossRef]

48. Volmer, J. Catching leaders' mood: Contagion effects in teams. Adm. Sci. 2012, 2, 203-220. [CrossRef]

49. Cropanzano, R.; Dasborough, M.T.; Weiss, H.M. Affective events and the development of leader-member exchange. Acad. Manag. Rev. 2017, 42, 233-258. [CrossRef]

50. Hatfield, E.; Carpenter, M.; Rapson, R.L. Emotional contagion as a precursor to collective emotions. Collect. Emot. Perspect. Psychol. Philos. Sociol. 2014, 108-122. [CrossRef]

51. Engle, E.M.; Lord, R.G. Implicit theories, self-schemas, and leader-member exchange. Acad. Manag. J. 1997, 40, $988-1010$.

52. George, J.M.; Bettenhausen, K. Understanding prosocial behavior, sales performance, and turnover: A group-level analysis in a service context. J. Appl. Psychol. 1990, 75, 698. [CrossRef]

53. Totterdell, P.; Kellett, S.; Teuchmann, K.; Briner, R.B. Evidence of mood linkage in work groups. J. Personal. Soc. Psychol. 1998, 74, 1504. [CrossRef]

54. Newcombe, M.J.; Ashkanasy, N.M. The role of affect and affective congruence in perceptions of leaders: An experimental study. Leadersh. Q. 2002, 13, 601-614. [CrossRef]

55. George, J.M. Emotions and leadership: The role of emotional intelligence. Hum. Relat. 2000, 53, 1027-1055. [CrossRef]

56. Nielsen, M.B.; Glasø, L.; Einarsen, S. Exposure to workplace harassment and the Five Factor Model of personality: A meta-analysis. Personal. Individ. Differ. 2017, 104, 195-206. [CrossRef]

57. Öztürk, D.; Aşcigil, S.F. Workplace Bullying among Public Sector Employees. Bus. Prof. Ethics J. 2017, 36, 103-126. [CrossRef]

58. Ford, M.T.; Agosta, J.P.; Huang, J.; Shannon, C. Moral emotions toward others at work and implications for employee behavior: A qualitative analysis using critical incidents. J. Bus. Psychol. 2018, 33, 155-180. [CrossRef]

59. Kraak, J.M.; Lunardo, R.; Herrbach, O.; Durrieu, F. Promises to employees matter, self-identity too: Effects of psychological contract breach and older worker identity on violation and turnover intentions. J. Bus. Res. 2017, 70, 108-117. [CrossRef]

60. Thomas, D.C. Beyond identity: Membership norms and regional organization. Eur. J. Int. Relat. 2017, 23, 217-240. [CrossRef]

61. Baer, M.D.; Van Der Werff, L.; Colquitt, J.A.; Rodell, J.B.; Zipay, K.P.; Buckley, F. Trusting the "look and feel": Situational normality, situational aesthetics, and the perceived trustworthiness of organizations. Acad. Manag. J. 2018, 61, 1718-1740. [CrossRef] 
62. Robinson, S.L. Trust and breach of the psychological contract. Adm. Sci. Q. 1996, 574-599. [CrossRef]

63. Robinson, S.L.; Wolfe Morrison, E. The development of psychological contract breach and violation: A longitudinal study. J. Organ. Behav. 2000, 21, 525-546. [CrossRef]

64. Flood, P.C.; Turner, T.; Ramamoorthy, N.; Pearson, J. Causes and consequences of psychological contracts among knowledge workers in the high technology and financial services industries. Int. J. Hum. Resour. Manag. 2001, 12, 1152-1165. [CrossRef]

65. Cohen, A. A global evaluation of organizational fairness and its relationship to psychological contracts. Career Dev. Int. 2013. [CrossRef]

66. Robinson, S.L.; Rousseau, D.M. Violating the psychological contract: Not the exception but the norm. J. Organ. Behav. 1994, 15, 245-259. [CrossRef]

67. Payne, K.; Cangemi, J.; Kohler, P.; FUQUA JR, H. Violation of the Psychological Contract and the Development of Unions and Strikes: The Defense of the Individual's Employment Rights. J. Individ. Employ. Rights 1998, 7, 33-47. [CrossRef]

68. Ward, S.G.; Envick, B.R.; Langford, M. On the theory of psychological contracts in family firms. Entrep. Exec. $2007,12,37$.

69. Arasli, H.; Bavik, A.; Ekiz, E.H. The effects of nepotism on human resource management. Int. J. Sociol. Soc. Policy 2006. [CrossRef]

70. Chrisman, J.J.; Sharma, P.; Steier, L.P.; Chua, J.H. The Influence of Family Goals, Governance, and Resources on Firm Outcomes; Sage Publications: Thousand Oaks, CA, USA, 2013.

71. Caroline, U.N. Absenteeism, favouritism, and tardiness as predictors of job deviance in academia: The Nigeria experience. J. Soc. Sci. Humanit. 2015, 1, 75-81.

72. David, K.; Singh, H. Acquisition regimes: Managing cultural risk and relative deprivation in corporate acquisitions. Int. Rev. Strateg. Manag. 1993, 4, 227-276.

73. Neckebrouck, J.; Schulze, W.; Zellweger, T. Are family firms good employers? Acad. Manag. J. 2018, 61, 553-585. [CrossRef]

74. Barnett, T.; Kellermanns, F.W. Are we family and are we treated as family? Nonfamily employees' perceptions of justice in the family firm. Entrep. Theory Pract. 2006, 30, 837-854. [CrossRef]

75. Colquitt, J.A.; Conlon, D.E.; Wesson, M.J.; Porter, C.O.; Ng, K.Y. Justice at the millennium: A meta-analytic review of 25 years of organizational justice research. J. Appl. Psychol. 2001, 86, 425. [CrossRef]

76. Cropanzano, R.; Byrne, Z.S.; Bobocel, D.R.; Rupp, D.E. Moral virtues, fairness heuristics, social entities, and other denizens of organizational justice. J. Vocat. Behav. 2001, 58, 164-209. [CrossRef]

77. Anderson, J.C.; Gerbing, D.W. Structural equation modeling in practice: A review and recommended two-step approach. Psychol. Bull. 1988, 103, 411. [CrossRef]

78. Mhatre, K.H.; Riggio, R.E.; Riggio, H.R. Nepotism and leadership. In Nepotism in Organizations; Routledge/Taylor \& Francis Group: Thames, UK, 2012; pp. 195-222.

79. Podsakoff, N. Common method biases in behavioral research: A critical review of the literature and recommended remedies. J. Appl. Psychol. 2003, 88, 879. [CrossRef] [PubMed]

80. Tepper, B.J. Consequences of abusive supervision. Acad. Manag. J. 2000, 43, 178-190.

81. Mael, F.; Ashforth, B.E. Alumni and their alma mater: A partial test of the reformulated model of organizational identification. J. Organ. Behav. 1992, 13, 103-123. [CrossRef]

82. Arasli, H.; Tumer, M. Nepotism, Favoritism and Cronyism: A study of their effects on job stress and job satisfaction in the banking industry of north Cyprus. Soc. Behav. Personal. Int. J. 2008, 36, 1237-1250. [CrossRef]

83. McGorry, S.Y. Measurement in a cross-cultural environment: Survey translation issues. Qual. Mark. Res. Int. J. 2000. [CrossRef]

84. Hayes, A.F. Introduction to Mediation, Moderation, and Conditional Process Analysis: A Regression-Based Approach; Guilford Publications: NewYork, NY, USA, 2017.

85. Hair, J.; Anderson, R.; Tatham, R.; Black, W. Multivariate Data Analysis; Prentice Hall: Upper Saddle River, NJ, USA, 1998.

86. Fornell, C.; Larcker, D.F. Evaluating structural equation models with unobservable variables and measurement error. J. Mark. Res. 1981, 18, 39-50. [CrossRef]

87. Preacher, K.J.; Hayes, A.F. SPSS and SAS procedures for estimating indirect effects in simple mediation models. Behav. Res. Methods Instrum. Comput. 2004, 36, 717-731. [CrossRef] [PubMed]

88. Liu, W.; Zhang, P.; Liao, J.; Hao, P.; Mao, J. Abusive supervision and employee creativity. Manag. Decis. 2016. [CrossRef]

89. Wei, F.; Si, S. Psychological Contract Breach, Negative Reciprocity, and Abusive Supervision: The Mediated Effect of Organizational Identification. Manag. Organ. Rev. 2013, 9, 541-561. [CrossRef]

90. Epitropaki, O. Transformational leadership, psychological contract breach and organizational identification. In Academy of Management Proceedings; Academy of Management, Briarcliff Manor: New York, NY, USA, 2003; pp. M1-M6.

91. Epitropaki, O. A multi-level investigation of psychological contract breach and organizational identification through the lens of perceived organizational membership: Testing a moderated-mediated model. J. Organ. Behav. 2013, 34, 65-86. [CrossRef]

92. Shahnawaz, M.; Goswami, K. Effect of psychological contract violation on organizational commitment, trust and turnover intention in private and public sector Indian organizations. Vision 2011, 15, 209-217. [CrossRef]

93. Ponting, S.S.-A. Organizational identity change: Impacts on hotel leadership and employee wellbeing. Serv. Ind. J. 2020, 40, 6-26. [CrossRef]

94. Arasli, H.; Evrim Arici, H.; Ilgen, H. Blackbox between job crafting and job embeddedness of immigrant hotel employees: A serial mediation model. Econ. Res.-Ekon. Istraživanja 2019, 32, 3953-3962. [CrossRef] 